\title{
A new species of Bolboforma (Incertae Sedis) from the Miocene of the Vøring Plateau, northern Norway
}

\author{
ANDREA POWELL \\ Department of Geology, University of Exeter, Devon, England
}

\begin{abstract}
A new species, Bolboforma fragori sp. nov., is described and figured from D.S.D.P. Leg 38 Site 341, and its stratigraphic position downhole is documented.
\end{abstract}

\section{INTRODUCTION}

Bolboforma fragori is a new species belonging to the Incertae Sedis group Bolboforma Daniels \& Spiegler, 1974. There is speculation about the affinities of the group: for example, Rögl \& Hochuli (1976) suggest that they may be planktonic algae (Chrysomondales) and Muller et al. (1985) believe that they may be algal reproductive bodies. Previously documented species have a limited stratigraphic occurrence. However, they also show a restricted geographic occurrence which may limit their use as zone fossils (Murray, in press). Despite this, they are distinctive in occurring in large numbers for short periods of time, and are common contributors to Oligocene, Miocene and Pliocene assemblages.

\section{AREA OF STUDY \\ The specimens were obtained from D.S.D.P. Leg 38 Site 341 situated on the Vøring Plateau (lat. $67^{\circ} 20.10^{\prime} \mathrm{N}$; long. $06^{\circ} 06.64^{\prime} \mathrm{E}$ ). It was cored in $1439 \mathrm{~m}$ of water. For location of Site 341 see Fig. 1.}

\section{MATERIAL AND RESULTS}

Thirty one samples were washed on a $63 \mu \mathrm{m}$ sieve and the benthic foraminifera and Bolboforma assemblages picked and mounted. Specimens of $B$. fragori sp. nov. were found in the following core sections:

341-26-3, 123-127cm: 355m downhole.

341-27-2, 92-96cm: $372 \mathrm{~m}$ downhole.

341-28-4, 49-54cm: 394m downhole.

341-29-2, 123-127cm: 402.5m downhole.

All samples bearing $B$. fragori were obtained from the Lithologic Unit $3 \mathrm{~b}$. This is described as a massive brownish grey to dark greenish grey calcareous diatomite and calcareous diatomaceous mudstone. The unit is $46.5 \mathrm{~m}$ thick and has been assigned a Middle Miocene age (Talwani et al., 1976).

Above core 26 the sequence has a large reworked element due to slumping as a result of diapirism. This explains the presence of Bolboforma intermedia Daniels \& Spiegler, 1974 and B. aculeata Daniels \& Spiegler, 1974, in sample $341-7-2,68-72 \mathrm{~cm}(59 \mathrm{~m}$ downhole) giving an Upper Miocene age to predominantly Plio-Pleistocene sediments.

Cores 26 and 27 have occasional bands of calcareous benthic foraminifera preserved; many are etched suggesting that the Miocene sediments were deposited near to the Calcium Carbonate Compensation Depth.

In sample $341-26-3,123-127 \mathrm{~cm}$ the assemblage comprises predominantly $B$. fragori. A moderately diverse benthic foraminiferal assemblage was found in association with this. Melonis barleeanus (Williamson), Oridorsalis umbonatus (Reuss), and Pullenia osloensis Feyling-Hanssen are the dominant species with Cibicidoides aff. $C$. bradyi (Trauth), Martinottiella and Heterolepa spp. as accessory species.

The occurrence of all Bolboforma species recovered from Site 341 is summarised in Table 1.

\section{SYSTEMATIC DESCRIPTION} Incertae Sedis

Genus Bolboforma Daniels \& Spiegler, 1974 Bolboforma fragori sp. nov. (Pl. 1, figs. 1-4)

Derivation of name. Fragor(n) (Latin), meaning splash; which refers to the style of the ornament.

Diagnosis. A species of Bolboforma compressed parallel to the equatorial plane with three variably developed lateral concentric flanges which are ornamented with invaginations and round ended processes.

Holotype. Deposited at the British Museum (Natural History), no. ZF 4626. (Paratypes: ZF 4627-4636). Material. Specimens were obtained in abundance $(>70$ specimens) from samples 341-26-3 and 341-28-4. Single specimens were recorded from samples $341-27-2$ and 341-29-2.

Type locality. D.S.D.P. Site 341 (355m downhole). Vøring Plateau, lat. $67^{\circ} 20.10^{\prime} \mathrm{N}$; long. $06^{\circ} 6.64^{\prime} \mathrm{E}$, off the N.E. coast of Norway.

Type lithology. Grey to dark greenish grey calcareous diatomite and calcareous diatomaceous mudstone. Age. Middle to Late Miocene (N15-N16). 


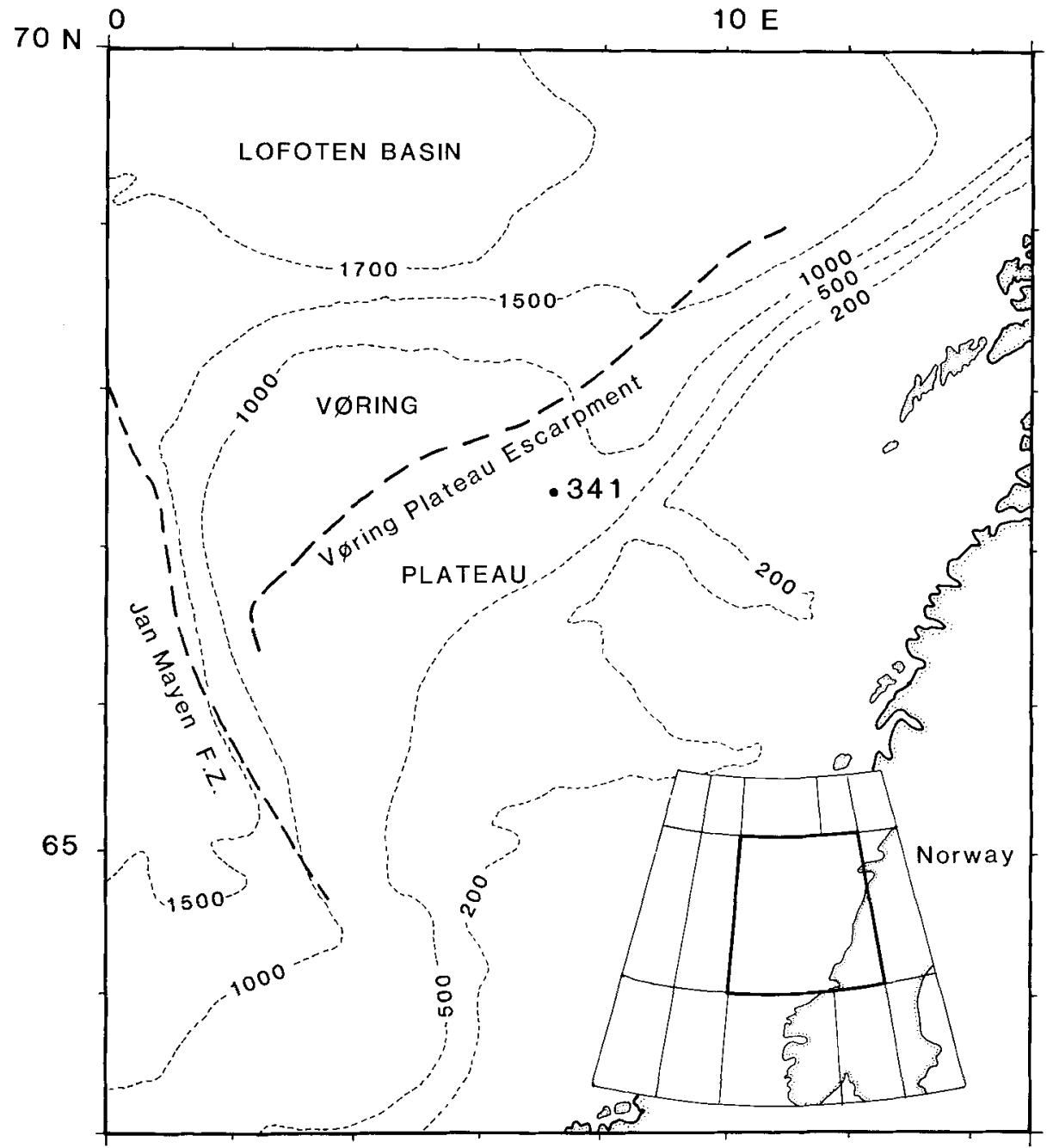

Fig. 1. Location of Vøring Plateau, approximate bathymetry (in nominal fathoms) and positions of Jan-Mayen Fracture Zone, Vøring Plateau Escarpment and D.S.D.P. Site 341. Inset: Area of Fig. 1. (after Talwani et. al. 1976).

\section{Explanation of Plate 1}

Fig. 1 a-c. Holotype, no. ZF 4626, sample 341-26-3: a, oral view; b, side view; c, aboral view (all $\times 235$ ).

Fig. 2. Paratype, no. ZF 4634, sample 341-26-3, oral view $(\times 235)$.

Fig. 3. Paratype, no. ZF 4636, sample 341-26-3, side view $(\times 235)$.

Fig. 4. Paratype, no. ZF 4636, sample 341-26-3, aboral view $(\times 235)$. 

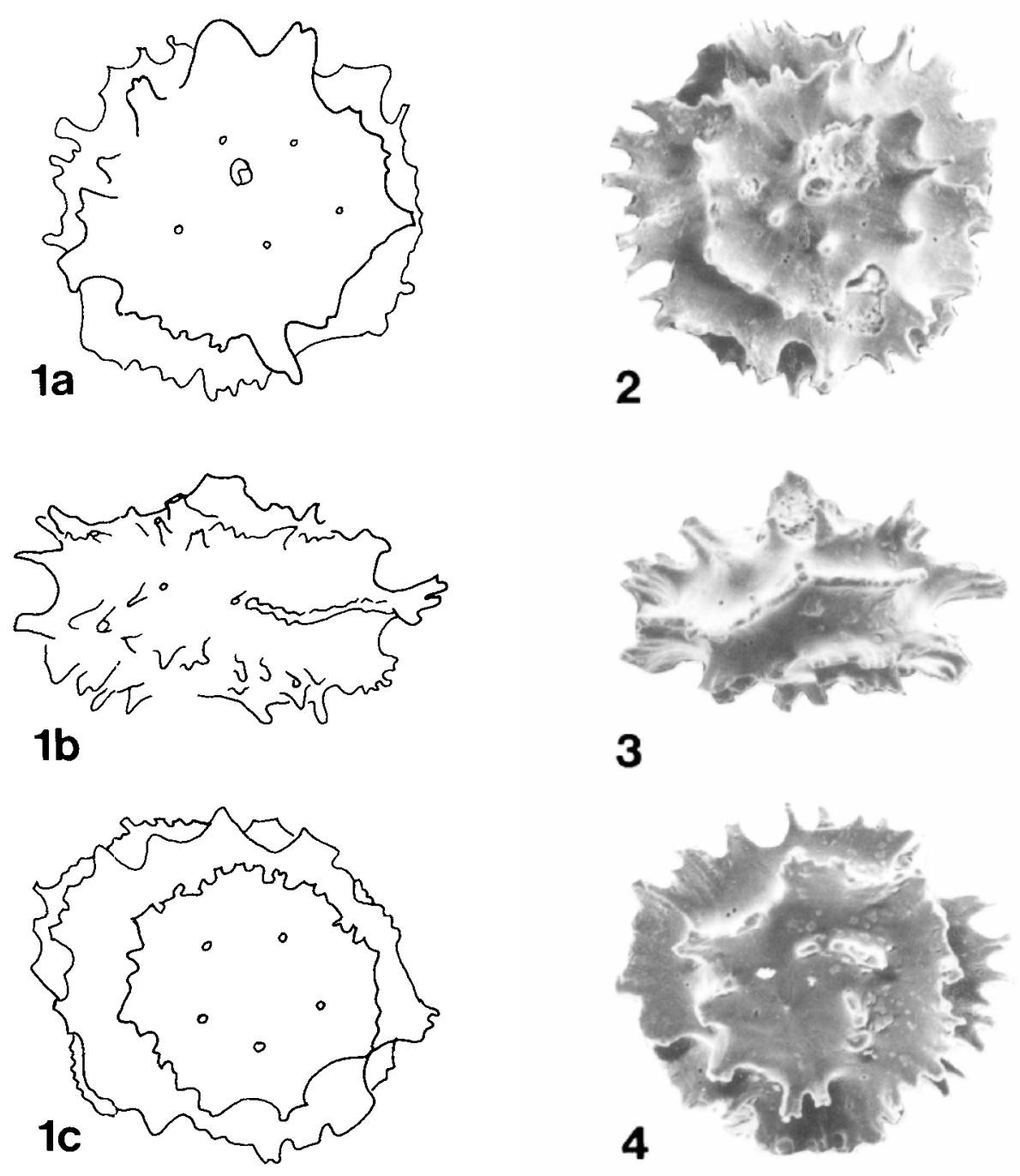


\begin{tabular}{llllll}
\hline $\begin{array}{c}\text { Sample } \\
\text { Number }\end{array}$ & Age & Intermedia Aculeata Fragori Laevis Metzmacheri Pseudohystrix Clodius \\
\hline
\end{tabular}

\begin{tabular}{ccccccc}
\hline $341-7-2$ & PLEISTOCENE & $\mathrm{r}$ & $\mathrm{r}$ & & & \\
\hline $341-26-3$ & L-M. MIOCENE & & $\mathrm{r}$ & $\mathrm{a}$ & $\mathrm{r}$ & \\
\hline $341-27-2$ & M. MIOCENE & & $\mathrm{r}$ & & & \\
\hline $341-28-2$ & M. MIOCENE & $\mathrm{r}$ & $\mathrm{a}$ & $\mathrm{a}$ & $\mathrm{a}$ & $\mathrm{r}$ \\
\hline $341-29-2$ & M. MIOCENE & & $\mathrm{r}$ & & & $\mathrm{r}$ \\
\hline
\end{tabular}

Table 1. Stratigraphic occurrence of species of Bolboforma recovered from D.S.D.P. Site 341. Sample numbers give site core and section. $\mathrm{a}=$ abundant; $\mathrm{r}=$ rare; blank $=$ no occurrence.

Description. Shell single chambered, compressed parallel to the equatorial plane, oral face with a short neck at the end of which is a circular aperture. The aboral surface is flattened. There are three lateral concentric flanges; the upper flange spirals down from the oral surface, whilst the lower flange spirals up from the aboral surface. These meet at the middle at a "central" flange which is discontinuous to accommodate the spirals. One end of this central flange bifurcates. The "central flange" is most prominent. The flanges are ornamented with invaginations and round ended processes. A circle of 3 to 8 round ended processes surrounds the apertural neck, and a similar row ornaments the aboral surface. The wall is glassy in appearance and calcitic.

Dimensions. $165-215 \mu \mathrm{m}$ in diameter, including ornament.

Remarks. Apertural neck length may vary, and the aperture may or may not possess a tooth plate. Ornament is commonly poorly preserved. No previously described species of Bolboforma bears flanges that are discontinuous spirals. All specimens viewed with a light microscope appear to bear three distinct continuous concentric flanges, however, under the S.E.M. only a few specimens exhibited this. The S.E.M. study revealed that the degree of spiralling of the flanges is variable. Some specimens show three distinct concentric flanges, but the central one is discontinuous and bifurcates at one end, whilst others do exhibit three truly concentric flanges. Differences in the degree of development of the flanges are considered to be variations within this species.

Comparison. There is a superficial resemblance to $B$. aculeata Daniels \& Spiegler, 1974 in the nature of the processes; and to $B$. intermedia Daniels \& Spiegler, 1974 , which bears a flange which is a single continous spiral.

\section{CONCLUSIONS}

Bolboforma fragori sp. nov. is recorded from the Middle to Late Miocene sediments of D.S.D.P. Site 341 on the Vøring Plateau. Samples of similar age from D.S.D.P. Sites 116, 352, and 336; and a selection of cores from the northern North Sea and West of Shetland shelf have been studied by the author. No specimens of $B$. fragori have been recovered from these cores. The stratigraphic and geographic range of $B$. fragori will hopefully be augmented by further studies.

\section{ACKNOWLEDGEMENTS}

I am very grateful to Dr. C. von Daniels for checking the specimens and to Prof. J. W. Murray for critical comment on both the specimens and this manuscript. Mr. J. S. Jones prepared the plates.

\section{Manuscript submitted November 1985 Manuscript accepted April 1986}

\section{REFERENCES}

Daniels, C. H. von \& Spiegler, D. 1974. Bolboforma n.gen.(Protozoa?) eine neue stratigraphisch wichtige Gattung aus dem Oligozän/Miozän Nordwestdeutschlands. Paläont. Zeitschr., 48, pp, 57-76.

Muller, C., Spiegler, D. \& Pastouret, L. 1981. The genus Bolboforma Daniels and Spiegler in the Oligocene and Miocene sediments of the North Atlantic and Northern Europe. In Graciansky, P. C. de, Poag, C. W., et al. 1985. Init. Rep. Deep Sea Drilling Project, 80, Washington (U.S. Govt. Printing Office.), 669-675.

Murray, J. W. In press. Bolboforma from North Atlantic sites, D.S.D.P. Leg 94. Deep Sea Drilling Project, Leg 94 manuscript.

Rögl, F. \& Hochuli, P. 1976. The occurrence of Bolboforma, a probable algal cyst, in the Antarctic Miocene of D.S.D.P. Leg 35. In Hollister et al. 1976. Init. Rep. Deep Sea Drilling Project, 35, Washington (U.S. Govt. Printing Office), 173.

Talwani, M., Udintsev, G. et al. 1976. Init. Rep. Deep Sea Drilling Project, 38, Washington (U.S. Govt. Printing Office), 1256pp. 